\title{
Distribution of Fin-fish Eggs and Larvae from Point Calimere and Muthupettai, South East Coast of India
}

Srilatha G*, Mayavu P, Varadharajan D and Chamundeeswari K

Faculty of Marine Sciences, Centre of Advanced Study in Marine Biology, Annamalai University, Parangipettai-608502, Tamil Nadu, India

\begin{abstract}
Eggs and larvae of the fishes are known as Ichthyoplankton. Mostly, the eggs are a planktonic and they cannot swim effectively and drift with the ocean currents. A fish larva is a part of zooplankton there consumes small organisms. It is a bio-indicator of an aquatic ecosystem. In the present study, totally $748 / 100 \mathrm{~m}^{3}$ fish eggs were collected from both the stations of Point Calimere and Muthupettai. The finfish eggs were recorded maximum in $18 / 100 \mathrm{~m}^{3}$ and $24 / 100 \mathrm{~m}^{3}$ at station I and II and the larvae were recorded maximum in 8/100 $\mathrm{m}^{3}$ and $12 / 100 \mathrm{~m}^{3}$ at station I and II respectively. When compare two sampling station the maximum of fish eggs and larvae were observed station I than there other station. Sensitive development stages of the fish, like egg and larvae which can affect mainly on predatory problem, environmental parameters and manmade activities. The true diversity date is need for the species conservation and maintenance.
\end{abstract}

Keywords: Early life history; Fishes; Eggs; Larvae; Distribution; Evolutionary science

\section{Introduction}

The distribution of finfish eggs and larvae often area will help in a great deal in capture management and also useful in locating shoals of fish and their breeding grounds of ecosystem [1]. Though many works are available on the abundance of fish eggs and larvae in Indian water [2-5], this type of work has not been probed in Point Calimere and Muthupettai, which is said to have great larval resources, hence the present study has been carried out to find out the distribution of fin fish eggs and larvae Point Calimere and Muthupettai.

\section{Materials and Methods}

\section{Sampling procedure}

The samples were collected fortnightly intervals during the period of September 2006 to August 2007. The samples is with the help of plankton net made in Number of 20 bolting silk with a mesh size of $0.076 \mathrm{~mm}$ measuring one half meters in length and $405 \mathrm{~mm}$ wide at the mouth from two stations at Point Calimere and Muthupettai mangroves area, monthly samples of Ichthyoplankton were also made employing the same net from station 1 and 2 .

The collected samples were preserved in $10 \%$ formalin and brought to the laboratory and the fish eggs and larvae were picked out from the whole sample and again preserved in 5\% neutralized formalin for detailed method of $[2,6]$. Samples from all the stations were preserved onboard in 5\% buffered formalin-seawater and sorted in the laboratory [7]. Fin fish eggs and larvae were sorted out from this sample and their abundance was expressed as Number of eggs/100 $\mathrm{m}^{3}$. For the identification of eggs and larvae of fin fishes are the earlier investigations made by [8-16]. A suite of statistical analyze were carried out using statistical packages SPSS Version 11.5.

\section{Species diversity}

To express the species diversity of the stations the Shannon-Wiener species diversity index was used. The formula is;

$$
\mathrm{Y}=\frac{\mathrm{N}}{\mathrm{N}} \sum_{\mathrm{i}=\mathrm{i}}^{\mathrm{n}} \mathrm{yi}
$$

\section{Shannon-Wiener diversity $\left(\mathrm{H}^{\prime}\right)$}

To assess the species diversity, the following formula of [17] was used.

$$
\begin{aligned}
& \mathrm{H}^{\prime}=-\Sigma^{\mathrm{s}} \text { pi } \log \mathrm{pi} \\
& \mathrm{i}=1
\end{aligned}
$$

This can also be written as

$\frac{\mathrm{H}^{\prime}=3.3219(\mathrm{~N} \log \mathrm{N}-\Sigma \mathrm{ni} \log \mathrm{ni})}{\mathrm{N}}$

Where $\mathrm{H}^{\prime}=$ Species diversity

$\mathrm{Ni}=$ No. of individuals of the ith species

$\mathrm{N}=$ Total number of the individuals in the collection and

$\Sigma=$ Sum

\section{Simpson index (D')}

Species richness was calculated by [18] formula.

$\mathrm{D}=1-\mathrm{C}$

Where, $\mathrm{C}=\Sigma \mathrm{P}$ i2

$\mathrm{Pi}=\mathrm{ni} / \mathrm{N}$

ni-no. of individuals of $i_{1}, i_{2}$, etc and

$\mathrm{N}=$ Total number of individuals

*Corresponding author: G. Srilatha, Faculty of Marine Sciences, Centre of Advanced Study in Marine Biology, Annamalai University, Parangipettai-608 502, Tamil Nadu, India, Tel: 04144-243223; Fax: 04144-243553; E-mail: srigovisaro@gmail.com

Received June 18, 2013; Accepted July 24, 2013; Published July 26, 2013

Citation: Srilatha G, Mayavu P, Varadharajan D, Chamundeeswari K (2013) Distribution of Fin-fish Eggs and Larvae from Point Calimere and Muthupettai, South East Coast of India. J Aquac Res Development 4: 178 doi:10.4172/21559546.1000178

Copyright: $\odot 2013$ Srilatha G, et al. This is an open-access article distributed under the terms of the Creative Commons Attribution License, which permits unrestricted use, distribution, and reproduction in any medium, provided the original author and source are credited. 


\section{Pielou's evenness $\left(\mathrm{J}^{\prime}\right)$}

Evenness (or) equality $\left(\mathrm{J}^{\prime}\right)$ in the distribution of individuals among the various species was calculated using the formula of [19]

$$
\begin{aligned}
& J^{\prime}=\mathrm{H}^{\prime} / J n s \text { or } \mathrm{H}^{\prime} / \log 2^{5} \\
& \text { Where, J'=Evenness } \\
& \mathrm{H}^{\prime}=\text { Species diversity and } \\
& \mathrm{S}=\text { Total number of species }
\end{aligned}
$$

\section{Results}

\section{Distribution of fish eggs and larvae}

Total number of 748/100 $\mathrm{m}^{3}$ fish eggs was collected from both the stations of Point Calimere and Muthupettai during the study period.

\section{Finfish eggs in point calimere and muthupettai}

A total number of $18 / 100 \mathrm{~m}^{3}$ finfish eggs were recorded in Point Calimere. Such as, Ophichthys sp., Setipinna taty, Stolephorus tri, Stolephorus punctifer, Thryssa dussumieri, Optsthopterus tardoore, Sardinella fimbriata, Sardinella gibbosa, Saurida gracilis, Sarus sp., Ambassis commersoni, Epinephelus sp., Caranx sp., Scomberomorus sp., Cynoglossus arel, Elops machnata, Chirocentrus dorap and Chanos chanos were recorded in the stations.

A total number of $24 / 100 \mathrm{~m}^{3}$ finfish eggs were recorded in Muthupettai. Such as, Ophichthys sp., Setipinna taty, Stolephorus tri, Stolephorus punctifer, Thryssa dussumieri, Optsthopterus tardoore, Sardinella fimbriata, Sardinella gibbosa, Saurida gracilis, Sarus sp., Ambassis commersoni, Epinephelus sp., Caranx sp., Lutjanus sp., Liza tade, Liza dussumierri, Mugil cephalus, Himiramphus far, Hilsa kelee, Gerres oblongus, Terapon jarbua, Cynoglossus arel, Chirocentrus dorab and Platycephalus indicus were recorded in the stations.

\section{Finfish larvae in point calimere and muthupettai}

A total number of $8 / 100 \mathrm{~m}^{3}$ finfish larvae were recorded in Point Calimere. Such as, Stolephorus tri, Sardinella gibbosa, Ambassis commersoni, Scomberomorus sp., Elops machnata, Chirocentrus dorap, Lutjanus sp. and Atherina sp. were recorded in the stations.

A total number of $12 / 100 \mathrm{~m}^{3}$ finfish larvae were recorded in Muthupettai. Among this, Thryssa dussumieri, Sardinella gibbosa, Ambassis commersoni, Caranx sp., Lutjanus sp., Liza dussumierri, Mugil cephalus, Himiramphus far, Hilsa kelee, Gerres oblongus, Terapon jarbua and Scomberomorus sp., were recorded in the stations.

\section{Setipinna sp.:}

$\begin{array}{ll}\text { Phylum } & : \text { Chordata } \\ \text { Class } & : \text { Ostichphyes } \\ \text { Order } & : \text { Clupeiformes } \\ \text { Family } & : \text { Engraulidae } \\ \text { Genus } & : \text { Setipinna }\end{array}$

The eggs are completely spherical, colorless and transparent. The perivitelline space is very narrow and measured $1.26 \mathrm{~mm}$ in diameter. The segmented yolk contains 15 to 18 oil globules. In the present eggs are found 19 oil globules of uneven size, aggregated at the center of the yolk the diameter of yolk is $1.225 \mathrm{~mm}$ and that of the oil globules ranged from about $0.05 \mathrm{~mm}$ to $0.08 \mathrm{~mm}$ (Figure 1).

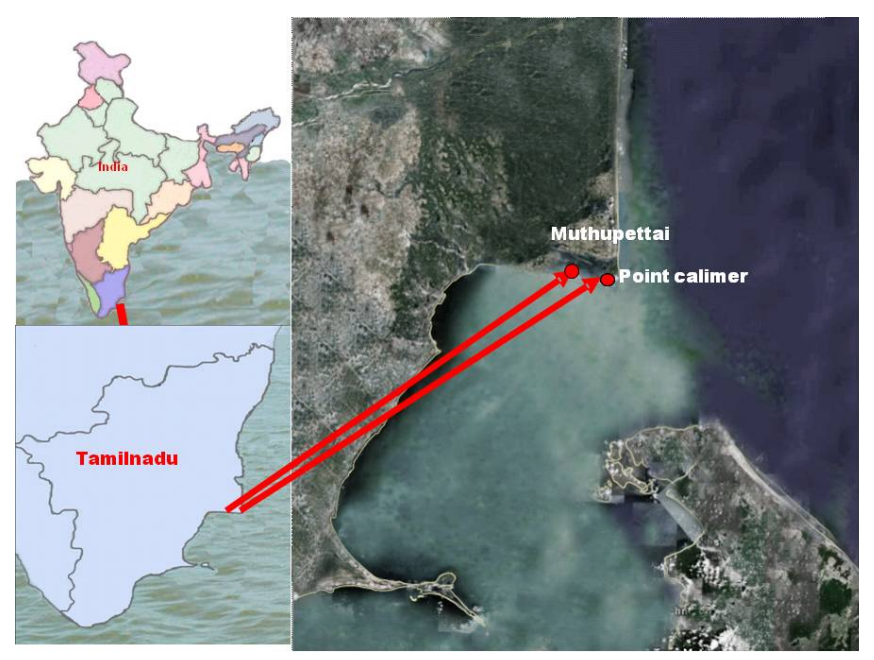

Figure 1: Map showing the study area.

Sardinella fimbriata:

$\begin{array}{ll}\text { Phylum } & \text { : Chordata } \\ \text { Class } & \text { : Ostichphyes } \\ \text { Order } & : \text { Clupeiformes } \\ \text { Family } & : \text { Clupeidae } \\ \text { Genus } & : \text { Sardinella } \\ \text { Species } & \text { : fimbriata }\end{array}$

Eggs are mostly found in pelagic, spherical, colorless and transparent. Diameter of the egg ranges between $1.36 \mathrm{~mm}$ and 1.41 $\mathrm{mm}$. Yolk is spherical, coarsely vacuolated, colorless and transparent. The diameter of the yolk ranges from 0.10 to $0.92 \mathrm{~mm}$. The yolk and embryo occupy half of the egg capsule, leaving a wide perivitelline space. Single, golden yellow colored oil globule is present on the yolk mass. Oil globule size was ranges from 0.09 to $0.13 \mathrm{~mm}$. Egg envelop is smooth and the embryonic pigmentation is absent. The embryo is well developed with head, trunk and caudal region but the caudal region is free from the yolk. The eyes, auditory vesicle and the myotimes are clearly visible. For present investigation, eggs were collected during July to September-2006, January, February, April, June and September-2007.

$\begin{array}{ll}\text { Sardinella gibbosa: } \\ \text { Phylum } & \text { : Chordata } \\ \text { Class } & \text { Ostichphyes } \\ \text { Order } & : \text { Clupeiformes } \\ \text { Family } & \text { : Clupeidae } \\ \text { Genus } & : \text { Sardinella } \\ \text { Species } & : \text { gibbosa }\end{array}$

The egg was spherical in shape and translucent with a diameter 0.6 $\mathrm{mm}$, yolk highly vacuolated and yellowish in colour and the diameter around $0.46 \mathrm{~mm}$, with an yellowish oil globule of $0.22 \mathrm{~mm}$ in diameter perivitelline space is wide, thus confirm the identity of egg as belonging to Sardinella gibbosa. Myotomes also visible through the transparency of body, few pigment spots are dispersed on head. 


\section{Stolephorus sp.:}

$\begin{array}{ll}\text { Phylum } & : \text { Chordata } \\ \text { Class } & : \text { Ostichphyes } \\ \text { Order } & : \text { Clupeiformes } \\ \text { Family } & : \text { Engraulidae } \\ \text { Genus } & : \text { Stolephorus }\end{array}$

The eggs are pelagic, transparent oval shaped and measured about $1.34 \mathrm{~mm}$ in length and $0.56 \mathrm{~mm}$ in breadth. The perivitelline space is very narrow. The yolk exhibits very clear segmentation. The oil globules is single, pale yellow, $0.07 \mathrm{~mm}$ in diameter and situated at the posterior most part of the yolk. A vacuole-like structure is seen just above the oil globule. The developing embryo is found to have 14 body somites and is free from any sort of pigmentation.

\section{Stolephorus tri:}

$\begin{array}{ll}\text { Phylum } & : \text { Chordata } \\ \text { Class } & : \text { Ostichphyes } \\ \text { Order } & : \text { Clupeiformes } \\ \text { Family } & : \text { Engraulidae } \\ \text { Genus } & : \text { Stolephorus } \\ \text { Species } & : \text { tri }\end{array}$

Eggs are mostly found in pelagic, transparent and oval formed measuring about $1.48 \mathrm{~mm}$ in length and $0.56-0.56 \mathrm{~mm}$ in breadth. The perivitelline space is very narrow. The yolk exhibits clear segmentation. The oil globule is single, pale yellow in colour; the diameter is around $0.08 \mathrm{~mm}$. The eggs were observed only in higher salinity.

\section{Thryssa sp.:}

$\begin{array}{ll}\text { Phylum } & : \text { Chordata } \\ \text { Class } & : \text { Ostichphyes } \\ \text { Order } & : \text { Clupeiformes } \\ \text { Family } & : \text { Engraulidae } \\ \text { Genus } & : \text { Thryssa }\end{array}$

The eggs are spherical with a diameter $1.10 \mathrm{~mm}$. The yolk is clear and segmented without oil globule. In the earliest stage obtained, the blastoderm has already begun to spread over the surface of the yolk and is in from of a cap over it. The perivitelline space is narrow. The size and shape of the eggs and other characters like coarsely segmented yolk, absence of pigmentation and oil globule show that the eggs described here are those of Thryssa sp.

\section{Saurida sp.:}

$\begin{array}{ll}\text { Phylum } & : \text { Chordata } \\ \text { Class } & : \text { Ostichphyes } \\ \text { Order } & : \text { Aulopiformes } \\ \text { Family } & : \text { Synodontidae } \\ \text { Genus } & : \text { Saurida }\end{array}$

Eggs are pelagic, spherical, colorless and transparent, measuring $2 \mathrm{~mm}$ in diameter. Yolk is spherical, unsegmented, Colorless and transparent: the diameter being $2.0 \mathrm{~mm}$. Perivitelline width is narrow. Net-work of hexagonal meshes is found on the egg membrane but pigments are absent.

\section{Sarus sp.:}

$\begin{array}{ll}\text { Phylum } & \text { : Chordata } \\ \text { Class } & \text { : Ostichphyes } \\ \text { Order } & : \text { Aulopiformes } \\ \text { Family } & : \text { Synodontidae } \\ \text { Genus } & : \text { Sarus }\end{array}$

The color of the egg is pale white, spherical in shape with bold hexangonal markings or the egg membrane. The diameter of the egg is $1.12 \mathrm{~mm}$. The yolk is rough in nature. There are 29 ridges on the egg membrane and the space between two ridges is $0.10-0.28 \mathrm{~mm}$. A total of 21 oil globules are countable of which, 3-6 are comparatively larger. Their average diameter is $0.09 \mathrm{~mm}$. The previtelline space is narrow. A few melanophores are present in the head region of the developing embryo and few stellate are also present in the chromatophores on the yolk.

\section{Cynoglossus sp.:}

$\begin{array}{ll}\text { Phylum } & \text { : Chordata } \\ \text { Class } & \text { : Ostichphyes } \\ \text { Order } & : \text { Pleuronictiformes } \\ \text { Family } & \text { : Soleidae } \\ \text { Genus } & : \text { Cynoglossus }\end{array}$

There were perfectly transparent spherical eggs with an average diameter of $0.84 \mathrm{~mm}$. The yolk was clear and unsegmented, with 18-22 yellowish oil globules of varying sizes. Very faint grayish chromatophoroes were sometimes seen on the surface of the yolk. The embryo was not fully formed in the morning when they were collected. The outline of the eyes and few my tones alone were distinguishable at this stage.

$\begin{array}{ll}\text { Caranx sp.: } & \\ \text { Phylum } & \text { : Chordata } \\ \text { Class } & \text { : Ostichphyes } \\ \text { Order } & \text { : Perciformes } \\ \text { Family } & : \text { Carangidae } \\ \text { Genus } & : \text { Caranx }\end{array}$

The diameter of the egg is spherical $0.79 \mathrm{~mm}$ having segmented yolk showing huge vacuole characteristics of carangid eggs. A single oil globule enclosed with yellow. Ramifying chromatophores could be seen. Black pigment cells are also present in the oil globules. The periviteline space is narrow.

\section{Scombermorus sp.:}

$\begin{array}{ll}\text { Phylum } & \text { : Chordata } \\ \text { Class } & : \text { Ostichphyes } \\ \text { Order } & : \text { Perciformes } \\ \text { Family } & : \text { Scombridae } \\ \text { Genus } & : \text { Scombermorus }\end{array}$


The eggs are totally spherical with a diameter ranging from 0.80 $\mathrm{mm}-0.086 \mathrm{~mm}$. The yolk is unsegmented with a single oil globule $(0.15$ to $0.18 \mathrm{~mm})$. In the earliest stage obtained presently, the embryo is somewhat advanced in development with the tail section being free from the yolk mass. The eyes and aural vesicles are well developed. The embryo performs. Occasional are jerking movements inside the egg membrane. Three small bands of chromatophores are present in the body. Several small pigments are sparsely distributed all over the yolk.

\section{Opisthoptrus sp.:}

$\begin{array}{ll}\text { Phylum } & \text { : Chordata } \\ \text { Class } & : \text { Ostichphyes } \\ \text { Order } & : \text { Clupeiformes } \\ \text { Family } & : \text { Pristigasteridae } \\ \text { Genus } & \text { : Opisthoptrus }\end{array}$

Eggs are pelagic, globular, colorless, transparent and devoid of oil globules. The diameter of the egg ranges between $0.76 \mathrm{~mm}$ to 0.89 $\mathrm{mm}$. The average diameter being $0.89 \mathrm{~mm}$. Yolk mass is spherical, well vacuolated, colorless and transparent. Perivitelline width is relatively narrow in living condition whereas, when preserved in formalin the yolk mass shrinks leaving a large perivitelline space, smooth envelop and pigments are not present.

\section{Sardinella clupeoides:}

$\begin{array}{ll}\text { Phylum } & \text { : Chordata } \\ \text { Class } & \text { : Ostichphyes } \\ \text { Order } & \text { : Clupeiformes } \\ \text { Family } & \text { : Clupeidae } \\ \text { Genus } & \text { : Sardinella } \\ \text { Species } & \text { : clupeoides }\end{array}$

Eggs are pelagic, spherical, Colorless and transparent. Eggs diameter ranges from 0.92 to $0.96 \mathrm{~mm}$. Yolk is spherical, vacuolated, Colorless and transparent. The Yolk diameter ranges from 0.51 to 0.53 $\mathrm{mm}$.oil globule are absent. Perivitelline width is large. Pigmentation is absent. In the late stage of embryonic development, the embryo has well defined head, trunk and tail.

\section{Chirocentrus dorab:}

$\begin{array}{ll}\text { Phylum } & : \text { Chordata } \\ \text { Class } & : \text { Ostichphyes } \\ \text { Order } & : \text { Clupeiformes } \\ \text { Family } & : \text { Chirocentridae } \\ \text { Genus } & : \text { Chirocentrus } \\ \text { Species } & : \text { dorab }\end{array}$

Eggs are mostly pelagic, spherical, colorless and translucent. Eggs diameter ranges between 1.62 to $1.9 \mathrm{~mm}$ (egg is easily recognized by their large size). Yolk mass is spherical, segmented, colorless and transparent, the yolk diameter range between $1.28 \mathrm{~mm}$. 7 to 20 small sized oil globules are distributed irregularly in the yolk mass. Perivitelline width is tapered. Envelop not smooth. But it has on top of its surface a network of fine folds, which give a honeycomb like appearance; the network is much better, too fine, the meshes barely having a diameter of $0.01 \mathrm{~mm}$. Unpigmented in nature.

\section{Liza tade:}

$\begin{array}{ll}\text { Phylum } & : \text { Chordata } \\ \text { Class } & : \text { Ostichphyes } \\ \text { Order } & : \text { Mugiliformes (Mullets) } \\ \text { Family } & : \text { Mugilidae (Mullets) } \\ \text { Genus } & : \text { Liza } \\ \text { Species } & \text { : tade }\end{array}$

Eggs are pelagic, spherical, colorless and transparent: the diameter of the eggs ranging between 0.62 to $0.72 \mathrm{~mm}$. Yolk is spherical, clear, and unsegmented. Single spherical shaped oil globule is present on the yolk mass, measuring 0.14 to $0.15 \mathrm{~mm}$ in diameter. Perivitelline width is narrow. A few brownish black pigment spots are present on the dorsal side of the body including had region, of the embryo, and such pigmentation is present on the oil globule also.

\section{Liza dussumieri:}

$\begin{array}{ll}\text { Phylum } & : \text { Chordata } \\ \text { Class } & : \text { Ostichphyes } \\ \text { Order } & : \text { Mugiliformes (Mullets) } \\ \text { Family } & : \text { Mugilidae (Mullets) } \\ \text { Genus } & : \text { Liza } \\ \text { Species } & : \text { dussumieri }\end{array}$

Eggs are pelagic, spherical, colorless and transparent: the diameter of the eggs ranging between 0.52 to $0.056 \mathrm{~mm}$ and the average diameter being $0.54 \mathrm{~mm}$.Yolk is spherical, clear, colorless, transparent and unsegmented. Single oil globule is occupying the anterior portion near the head region of the developing embryo. The size range of the oil globule is between 0.15 to $0.16 \mathrm{~mm}$ and the average diameter being $0.16 \mathrm{~mm}$. Perivitelline width is narrow. Pigmentation are present on the developing embryo; two patches of light yellowish brown pigments in the head region and black pigments intermingled with light yellowish brown chromatophorus on the trunk and tail regions and similar pigment spots were noticed on the oil globule also. In early stage the head trunk and tail are not clearly visible.

$\begin{array}{ll}\text { Mugil cephalus: } \\ \text { Phylum } & \text { : Chordata } \\ \text { Class } & \text { : Ostichphyes } \\ \text { Order } & \text { : Mugiliformes (Mullets) } \\ \text { Family } & \text { : Mugilidae (Mullets) } \\ \text { Genus } & : \text { Mugil } \\ \text { Species } & : \text { cephalus }\end{array}$

The eggs are pelagic, spherical and transparent measuring $0.69 \mathrm{~mm}$ in diameter. The perivitelline space is narrow. The yolk is unsegmented measuring $0.668 \mathrm{~mm}$ in diameter. A single oil globule situated at the center of the yolk is measuring $0.24 \mathrm{~mm}$ in diameter. Black and brownish pale yellow pigmentation are scattered all over the embryo, oil globule and also on the yolk. The identification of this egg is based on Yellow and Berner. 


\section{Taxonomical position and description of finfish larvae}

Hilsa kelee:

$\begin{array}{ll}\text { Phylum } & : \text { Chordata } \\ \text { Class } & : \text { Ostichphyes } \\ \text { Order } & : \text { Clupeiformes } \\ \text { Family } & : \text { Clupeidae } \\ \text { Genus } & : \text { Hilsa } \\ \text { Species } & : \text { kelee }\end{array}$

Post larva of Hilsa kelee commonly known as the five spot herring, one of the commercially important clupeids occurring in Indian coastal waters. The size of the larvae wide-ranging from 18 to $22 \mathrm{~mm}$. Body slender and packed together, but mouth is terminal. Lower jaw is longer than upper having a middle notch. The dorsal fin originates following the ventral but anal fin originates behind the end of dorsal and caudal fin deeply forked. The entire fin with attachment of rays while the rays in the pectoral become is visible in the upper portion. Dorsal, anal and ventral fins initiate below 19,28 and $16^{\text {th }}$ myotomes respectively. Dorsal fin has 18 soft rays.

\section{Chirocentrus dorab:}

$\begin{array}{ll}\text { Phylum } & : \text { Chordata } \\ \text { Class } & : \text { Ostichphyes } \\ \text { Order } & : \text { Clupeiformes } \\ \text { Family } & : \text { Chirocentridae } \\ \text { Genus } & : \text { Chirocentrus } \\ \text { Species } & : \text { dorab }\end{array}$

The body is elongated and compressed. The eye diameter is 0.5 $\mathrm{mm}$ in this specimen. The dorsal fin originates from $50^{\text {th }}$ mytome, 15 branched rays are present in the dorsal fin and 26 rays are present in the anal fin. Caudal fin is forked with 19 rays. Further, 54 pre anal and 17 post anal could be seen in this larvae. Minute teeth are seen an either of the jaw. The gut region is well developed. Few minute pigments are present in the caudal fin.

$\begin{array}{ll}\text { Mugil cephalus: } \\ \text { Phylum } & \text { : Chordata } \\ \text { Class } & \text { : Ostichphyes } \\ \text { Order } & : \text { Mugiliforms } \\ \text { Family } & : \text { Mugilidae } \\ \text { Genus } & : \text { Mugil } \\ \text { Species } & : \text { cephalus }\end{array}$

Body is compressed in this specimen. The first dorsal fin has 4 spines. The second dorsal with first spine is with 8 rays, anal fin with 3 spines and 8 rays and pectoral with 12 rays. Caudal fin shows the emarginated shape of adult; with 13-branched rays. Dorsal-lateral part of the body densely is pigmented with few pigment spots appearing on the opercula region. The post larva transforms into juvenile by the formation of adipose eyelids, scales, branchiostegals and long, sylinder gill-rackers.

$\begin{array}{ll}\text { Stolephorus indicus: } \\ \text { Phylum } & \text { : Chordata } \\ \text { Class } & \text { : Ostichphyes } \\ \text { Order } & \text { : Clupeiformes } \\ \text { Family } & : \text { Engraulidae } \\ \text { Genus } & \text { : Stolephorus } \\ \text { Species } & \text { : indicus }\end{array}$

The specimens varied from $20.0 \mathrm{~mm}$ to $24.0 \mathrm{~mm}$ in total length. Body elongate belly rounded, maxilla almost reaching preopercle or gill opening, origin of dorsal behind the origin of pelvic fin. Abdominal scutes restricted between pectoral and Pelvic fins origin of anal below the origin of dorsal. The entire fine with full complement of rays excepting pectoral maxilla exited up to the preopercle dorsal fin has 16 rays and anal has 17 rays. Caudal is forked with 19 rays.

\section{Antherinea sp.:}

$\begin{array}{ll}\text { Phylum } & : \text { Chordata } \\ \text { Class } & : \text { Ostichphyes } \\ \text { Order } & : \text { Perciformes } \\ \text { Family } & : \text { Chanididae } \\ \text { Genus } & : \text { Antherinea }\end{array}$

While the hatching time of the larvae size is $4 \mathrm{~mm}$ in length. And fully are matured larvae about $15 \mathrm{~mm}$. This silverside swims in small schools during daylight hours close to the shore line and disperses at night spreading over the reef. Nocturnal plankton is eater, its gut content containing mostly crustaceans and foraminiferans.

\section{Sardinella sp.:}

$\begin{array}{ll}\text { Phylum } & : \text { Chordata } \\ \text { Class } & : \text { Ostichphyes } \\ \text { Order } & : \text { Clupeiformes } \\ \text { Family } & : \text { Chanididae } \\ \text { Genus } & : \text { Sardinella }\end{array}$

The total length of specimens different from $20.00 \mathrm{~mm}-28.0 \mathrm{~mm}$ and body extended and round mouth oblique and wide blunt or pointed. Origin of anal fin below the adipose dorsal. Body is translucent with a characteristic pigment pattern. Post larvae of Sardinella sp. can readily be recognized by either side of the alimentary cannel an unpaired one at the posterior end of anal fin. This is the detailed character of the post larvae Sardinella sp. This fades away during the transformation into juvenile. In the post larvae collected presently, the ventral fins have not yet appeared. Rays is a dorsal, anal and pectoral fin is not separate. Teeth and scales are useful for the detection of the adult.

\section{Seasonal distribution of fin fish eggs and larvae}

The present study revealed that over all abundance of eggs and larvae was more in post monsoon (January to March) and summer (April to June), followed by pre-monsoon (July to September) and monsoon (October to December).

Summer: The summer abundance of eggs and larvae, their total number for the one year period being $133 / 100 \mathrm{~m}^{3}$ and $89 / 100 \mathrm{~m}^{3}$ 
individuals in Point Calimere, 203/100 $\mathrm{m}^{3}$ and $163 / 100 \mathrm{~m}^{3}$ individuals in Muthupettai.

Pre-monsoon: During this season, the abundance of egg and larvae their total numbers 112/10 $\mathrm{m}^{3}$ individuals of eggs and $99 / 100 \mathrm{~m}^{3}$ individuals of larvae were collected in Point Calimere and 232/100 $\mathrm{m}^{3}$ individuals of eggs and 135/100 $\mathrm{m}^{3}$ individuals in Muthupettai.

Monsoon: The total number of eggs and larvae are being $180 / 100 \mathrm{~m}^{3}$ individuals of eggs and $62 / 100 \mathrm{~m}^{3}$ individuals of larvae in Point Calimere and 204/100 $\mathrm{m}^{3}$ individuals of eggs and 100/100 $\mathrm{m}^{3}$ individuals of larvae Muthupettai.

Post-monsoon: The post monsoon season abundance of eggs and larvae their total number of eggs and larvae being $373 / 100 \mathrm{~m}^{3}$ and $55 / 100 \mathrm{~m}^{3}$ individuals in Point Calimere, $631 / 100 \mathrm{~m}^{3}$ and $77 / 100 \mathrm{~m}^{3}$ individuals in Muthupettai. The present study revealed that, over all eggs and larvae was more abundance of post monsoon and followed by pre-monsoon, summer, and monsoon.

\section{Eggs}

Population density: The eggs population density varied from (25 to 135.). Minimum 135.0 was recorded during post monsoon (February 2007). Whereas the maximum (25) during pre-monsoon (August 2007) in Point Calimere. At Muthupettai, the eggs population density varied from 55 to $253100 \mathrm{~m}^{3}$ ). The minimum (55) was recorded during premonsoon (August 2007) and the maximum (253) as recorded during pre-monsoon (September 2007). The results of two ways ANOVA was showed non-significant variations between the seasons and stations.

Species diversity index: At Point Calimere, diversity index ( $\left.\mathrm{H}^{\prime \prime}\right)$ varied from $3.25 \mathrm{~b}$ to 3.87 . The minimum (3.87) was recorded during pre-monsoon (August 2007) and maximum (3.87) was recorded during early monsoon (December 2007). At Muthupettai, diversity index value was ranged from $3.83 / 100 \mathrm{~m}^{3}$ to 4.48 . The minimum (3.83) was recorded in pre-monsoon (July 2007) and maximum (4.48) was recorded during early post monsoon (January 2007). The two ways ANOVA showed significant variations between the seasons and stations.

Species richness: At Point Calimere, the eggs richness value was varied from 0.90 to 0.92 . The minimum (0.90) was recorded during post monsoon (February 2007) and the maximum (0.92) was observed during summer (April 2007). The eggs richness values was ranged from 0.902 to 0.95 . The minimum $(0.90)$ was observed during post monsoon (February 2007) and the maximum (0.95) was recorded during post monsoon (January 2007). The two way ANOVA showed significant variations between the seasons and stations.

Species evenness index (J): At Point Calimere, eggs evenness index $(J)$ varied from 0.872 to 0.95 . Maximum (0.95) was recorded in monsoon (October 2007) and minimum (0.872) was recorded in post monsoon (March 2007). The eggs evenness values fluctuated from 88 to 96 . Minimum (88) was observed during pre monsoon (August 2007) and maximum (96) was recorded during monsoon (December 2006) in Muthupettai. The two way ANOVA was showed significant variations between the seasons $(\mathrm{p}<0.05)$ and stations $(\mathrm{p}<0.05)$.

\section{Larvae}

Population density: The Point Calimere, the larvae population density varied from (14.00 to 72.00 .). Minimum 14 was recorded during post monsoon (March 2007). Whereas, the maximum (72) during pre monsoon (September 2007). At Muthupettai, the larvae population density varied from 22 to $49100 \mathrm{~m}^{3}$. The minimum $\left(22100 \mathrm{~m}^{3}\right)$ was recorded during post monsoon (March 2007). The maximum (49 100 $\mathrm{m}^{3}$ ) as recorded during pre monsoon (September 2007). The two-way ANOVA showed non-significant variations between the seasons and stations.

Species diversity index: The species diversity index ( $\left.\mathrm{H}^{\prime \prime}\right)$ varied from 2.07 to 2.69. The minimum (2.07) was recorded during monsoon (November 2007) and maximum (2.69) was recorded during early pre monsoon (August 2007) in Point Calimere. At Muthupettai, diversity index ranged from 2.44 to 3.21 . The minimum (2.44) was recorded in monsoon (October 2006) and maximum (3.21) was recorded in pre monsoon (September 2007). The two way ANOVA was showed significant variations between the seasons $(\mathrm{p}<0.05)$ and stations $(\mathrm{p}<0.05)$.

Species richness (D): At Point Calimere, the larvae richness was varied from 0.72 to 0.836 . The minimum (0.72) was observed during monsoon (November 2007) and the maximum (0.83) was recorded in pre monsoon (August 2007). At Muthupettai, larvae richness varied from 30 to 38, the minimum (30) was recorded in pre monsoon (August 2007) and maximum (38) was recorded in pre monsoon (September 2007). The two way ANOVA showed significant variations between the season $(\mathrm{p}<0.05)$ and stations $(\mathrm{p}<0.05)$.

Species evenness index ( $\mathrm{J})$ : At Point Calimere, larvae evenness index (J) varied from 0.86 to 0.96 . Maximum (0.96) was recorded in pre-monsoon (August 2007) and minimum (0.86) was recorded during monsoon (December 2007). At Muthupettai, larvae evenness values fluctuated from 0.862 to 0.960 . Maximum (0.960) was observed during monsoon (December 2007) and minimum (0.862) was recorded during pre-monsoon (August 2006). The two way ANOVA showed significant variations between the seasons $(\mathrm{p}<0.05)$ and stations $(\mathrm{p}<0.05)$.

\section{Discussion}

Examination of seasonal settlement and recruitment can be noted to identify the most seasonable time to conducts censes of recruitment so as to draw annual predications. On the biodiversity front also the eggs and larvae attain and lot of importance. The results of present study revealed that 9 Families of eggs and larvae, 18 species of eggs and 8 species of larvae were recorded in Point Calimere and 24 species of eggs and 12 species of larvae in Muthupettai. The Ichthyoplankton distribution indicated spawning activity of coastal fish species that inhabit these areas. Coastal regions adjacent to estuaries providing favorable conditions for the development of fish species that sheltered these areas as nursery and protection for their eggs and larvae.

In many studies have been reported the independence between the spatial and temporal distribution of fish larvae and zooplankton. [20] Stated that the most common problem associated to plankton studies was the use of adequate mesh size to sample fish larvae and their prey. In general, larvae smaller than $10 \mathrm{~mm}$ preyed on plankton organisms is smaller than $200 \mu \mathrm{m}$. However, mesh sizes used to collect Ichthyoplankton generally exceed $200 \mu \mathrm{m}$. The weakening of Ekman transport in the coastal regions associated to the closed geotropic circulation pattern of the Bight prevents fish eggs and larvae to be adverted offshore [21].

The response to environmental variables has however been shown to be species specific [22], the spatial distribution of fish larvae was greatly influenced by hydrobiology [23], salinity and turbidity are important factors associated with larval fish abundance [24,25]. Meteorological and oceanographic conditions influence the feeding of organisms and currents can transport eggs and larvae by [26]. Definite relation in the 
occurrence and abundance of fish larvae influenced by temperature, salinity, $\mathrm{pH}$, dissolved oxygen.

It was evidenced by positive significant correlation $\mathrm{r}=0.344$; $\mathrm{r}=0.926 ; \mathrm{r}=0.982 ; \mathrm{r}=0.916$ between abundance of larvae and physical parameters and negative significant correlation value $\mathrm{r}=-0.048$ and $\mathrm{r}=-0.115$ between the larvae and total suspended solid and turbidity. Similar report has been reported in Arasalar estuary, Karaikal [27]. Present study also stated that summer the larvae were observed in high. It may be due to the spawning of the fishes during this season. It is evidenced by [28]. During the monsoon the larvae diversity was low, due to the low salinity, when the ecosystem dominated by rain fed freshwater influx draining from land irrigation enhanced and rivers, which shows with diversity. The similar report has been noted by [29].

In the present study, a total of 22 species of eggs and 15 species of larvae were recorded from both stations. Of which, larvae of Thryssa dussumieri, Lisa dussumier, Mugil cephalus, Hemiramphus far, Hilsa kelee, Caranx sp and Gerras oblogus were observed from only in Point Calimere. Distributions of fish eggs and larvae have low at station-1 than at station-2. It may be due the depth of water turbidity and total suspended solids. Summer the larvae were observed in high. Other studies found similar results in other areas: most coastal species know to breed at the Arrabida marine park during the spring and summer period [30-32].

A total $2018 / 100 \mathrm{~m}^{3}$ eggs and $729 / 100 \mathrm{~m}^{3}$ larvae belonging to 9 families were identified. A similar observation has also been other study area reported that a total of $32140 / 100 \mathrm{~m}^{3}$ eggs and $6582 / 100 \mathrm{~m}^{3}$ larvae were collected from plankton samples and 69 species belonging to 27 families were identified by [33], in related to this topic another work, a total of $35555 / 100 \mathrm{~m}^{3}$ larvae, representing 28 families and 63 taxa were collected samples in estuary at North Brazil by [31,34] described a similar type of works around $1254 / 100 \mathrm{~m}^{3}$ eggs and $2840 / 100 \mathrm{~m}^{3}$ larvae and fry of 17 fish species were also identified in White sea.

Rita Borges et al. [33] reported that the most abundant developmental stages of clupeoidae were $24.63 \%$ of the total catch. Other studies found similar results the most abundant group in Clupeoidae around $70.4 \%$ were recorded by Beligin, Yesim [34]. Regarding the distribution abundance of fish eggs and larvae the research area, the Clupeoidae constituted the dominant groups. Present investigation also revealed that Opichthidae, Carangidae, Channidae, Mugilidae and Sarranidae in the study area, and Mugil cephalus, Opichthidae sp and Scomberomorus sp were also recorded. The similar report recorded by Barletta and Emmanul $[33,35]$. Here it can conclude that, fish farming industry is an important source of seafood with to increase the fish production mainly on coastal regions. Generally, the fish farming is a major problem of seed resources. Hatchery and standard technology for the mass scale production of oceanic finfish seed from the natural environment is one of the important sources at present. The mangrove area of this sampling station is an important of fish production and rich in resources. It is suitable places of vertebrates by providing a breeding site and by giving protection. In that region, directly or indirectly are having point sources as waste substance though a small stream and non-point sources as runoff, which is mainly affects the quality of water and the availability of eggs and larvae diversity and developmental growth. An unaffected area is abundance of eggs and larvae to support the diversity of fishes. Should be avoid some of the pollute activities and need for species conservation and protection of the environment.

\section{References}

1. Manickasundaram M, Sivakumaran KP, Ramaiyan V (1987) Studies on the abundance of fish eggs and larvae in Coleroon estuary, South east coast of India. J Mar Biol Ass India 29: 354-357.

2. Venkataramanujam K, Ramamoorthi K (1972) Seasonal variation in fish eggs and larvae of Portonovo coastal waters. Proc Symp Warmwater Zooplank Spl Publ UNESCO/NIO. Goa, India.

3. Kowtal GV (1967) Occurrence and distribution of pelagic fish eggs and larvae in the Chilka lake during the year 1964 and 1965. Indian J Fish 14: 198-214.

4. Prabhakara Rao AV (1970) Observation on the larval ingress of the milk fish Chanos chanos (Forskal) into the Pulicat Lake. J Mar Biol Ass India 13: 249 257

5. Manickasundaram M, Ramaiyan V (1990) On some fish eggs and larvae from the Andaman and Nicobar seas. FORV Sagar Sampada. Proc First Workshop Sci Res.

6. Bensam P (1987) Observations on a few early developmental stages in some fishes of Porto Novo Coast, India. PhD Thesis, Annamalai University, TN, India

7. Ahlstrom EH, Moser HG (1976) Eggs and larvae of fishes and their role in systematic investigations and in fisheries. Rev Inst Beaches Marit 40: 379-398.

8. Delsman HC (1922) Fish eggs and larvae from Java sea. L. Chirocentrus dorab (Forsskal.) Treubia 3: 38-46.

9. Delsman HC (1931) Fish eggs and larvae from Java sea. 17 The genus Stolophorus, Trebia 13: 217-243.

10. Delsman HC (1933) Fish eggs and larvae from Java sea. 22 Clupeoides lile (C.V). Treubia 14: 247-249.

11. Delsman HC (1938) Fish eggs and larvae from the Java sea. Linnaeus Press. Amsterdam Holland, The Netherlands.

12. Vijayaraghavan $P$ (1957) Studies on the fish eggs and larvae of Madras coast Ph.D. thesis. University of Madras, India.

13. Venkataramanujam K, Ramamoorthi K (1983) Development of the eggs and larvae of Cynoglossus sp. Matsya 9-10: 78-81.

14. Ramanathan N, Natarajan R (1979) Flat fish eggs, larvae and their development. Aquacult 18: 349-366.

15. Thangaraja M (1982) Studies on development, distribution and abundance of fish eggs and larvae in the Vellar estuary, Porto-novo (South India) Ph.D. Thesis, Annamalai University, TN, India.

16. Manickasundaram M (1990) Studies on fish eggs and larvae of Coleroon estuary along the Southeast coast of India. Ph.D. Thesis, Annamalai University, TN, India.

17. Shannon CE, Weaver W (1949) The mathematical theory of communication Univ of Illinois press. Urbana

18. Pielou EC (1966) The measurement of diversity in different types of biological collections. J Theoret Biol 13: 131-144.

19. Simpson EH (1949) Measurement of diversity. Nat 163: 688.

20. Frank KT (1988) Multispecies larval fish associations: accident or daptation Can J Fish Aquat Sci 40: 754-762.

21. Bakun A, Parrish RH (1990) Comparative studies of coastal pelagic fish reproductive habitats: The Brazilian sardine (Sardinella aurita). J Cons Int Explor Mer 46: 269-283.

22. Tzeng W, Wang Y (1992) Structure, composition and seasonal dynamics of the larval and juvenile fish community in the mangrove estuary of Tanshui of river Taiwan. Mar Biol 113: 481-490.

23. Koubbi P, Ibanez F, Duhamel G (1991) Environmental influences on spatiotemporal oceanic distribution of ichthyoplankton around the Kerguelen Islands (Southern Ocean). Mar Ecol Prog Ser 72: 225-238.

24. Whitfiled AK (1994) Review of ichthyofaunal biodiversity in southern African estuary systems. Anneals de la Musee de la Republic Afrique Central.149-163.

25. Whitfiled AK (1994) Abundance of larval and juvenile marine fishes in the lower reaches of three Southern African estuaries with differing freshwater inputs. Mar Ecol Prog Ser 105: 257-267.

26. Cyrus DP, Blaber SJM (1987) The influence of turbidity on juvenile marine fish in the esturies of Natal, South Afirica. Cont Shelf Sci 7: 1411-1416.

27. Rajasegar M, Bragadeeswaran S, Senthil kumar R (2005) Distribution and 
Citation: Srilatha G, Mayavu P, Varadharajan D, Chamundeeswari K (2013) Distribution of Fin-fish Eggs and Larvae from Point Calimere and Muthupettai, South East Coast of India. J Aquac Res Development 4: 178 doi:10.4172/2155-9546.1000178

Page 8 of 8

abundance of fish eggs and larvae in Arasalar estuary, Karaikkal, South-east coast if India. J Environ Biol 26: 273-276.

28. Balachandran T (1991) Distribution of meroplanktors in relation to the thermocline in the Western Indian Ocean during day and night. J Mar Biol Ass India 33: 278-285.

29. Brinda S, Bragadeeswaran S (2005) Influence of physico-chemical propertieson the abundance of a few economically important juvenile fin-fishes of Vellar estuary. J Environ Biol 26: 109-112

30. Henriques MEJ, Goncalves VC, Almada (1999) The conservation of littoral fish communities: A case study at Arrabda coast (Portugal). In: Almada VC,Oliveia RF, Goncalves EJ (Eds) Behaviour and Conservation of littoral Fishes. ISPA Lisboa.
31. Evseenko SA, Andrianov DP, Mishin AV Naunmov AP (2006) Species composition and distribution of ichthyoplankton in the White sea. J Icthyol 46 : 640-652.

32. Rita B, Ricardo B, Emanuel JG (2007) Vertical structure of near shore larval fish assemblages in a temperate rocky coast. Mar Biol 151: 1349-1363.

33. Beligin H, Yesim AK (2002) The ichthyoplankton of Izmir Bay: One-year study of fish eggs and larvae. Ege University, Departmnt of Hydrobiology, Faculty of Fisheris 26: 1033-1042.

34. Barletta BA, Baretta M, Saint PU (2002) Structure and seasonal dynamics of larval fish in the Caete river estuary in North Brasil. Est Coast Shelf Sci 54: 193-206.

35. Emmanul BE, Onyema IC (2007) The plankton and fish of a tropical creek in south-western Nigeria. Turkis J fishes Aquat Sci 7: 105-113. 